\title{
Pesticide Formulations as a Key Factor Affecting Chlorpyrifos-Ethyl and Lambda-Cyhalothrin Performance against Spodoptera littoralis (Boisd.)

\author{
Abdel-fattah S. A. Saad ${ }^{1}$, El-Sayed H. M. Tayeb ${ }^{1}$, Ahmed E. M. Omar ${ }^{2}$, El-sayed M. Farag ${ }^{3}$,
} Ayat F. M. Shams ${ }^{4}$
}

\begin{abstract}
Formulation is a term used in various senses in various applications, and its fundamental meaning is the putting together of components in an appropriate relationships or structures, according to a formula. Several prepared formulations for chlorpyrifos-ethyl and lambdacyhalothrin as Emulsifiable Concentrate (EC) formulation were subjected to WHO chemical tests to find out which formulation is matching the requirements. The physicochemical properties of the standard commercial formulation versus the prepared formulation were determined. The emulsion stability test was determined according to WHO specification method. Besides, the determination of free acidity and alkalinity as well as, viscosity and surface tension.

The results of emulsion stability test indicated that the $\mathrm{ml}$ separation in the prepared formulation of chlorpyrifos was $0.1 \mathrm{ml}$ cream after $1 \mathrm{hr}$ in the case of hard water and $0.9 \mathrm{ml}$ in soft water for chlorpyrifos $48 \%+$ Calcium dodecyl benzene sulfonate (CaDBS) $2.6 \%+$ Triton X-100 $2.4 \%\left(F_{1}\right)$ compared to $<0.1 \mathrm{ml}$ and $<0.3 \mathrm{ml}$ in hard and soft water respectively in the second formulation which consists of chlorpyrifos $48 \%$ + dodecyl benzene sulfonate (CaDBS) $2.8 \%+$ Triton X-100 2.2\% $\left(F_{2}\right)$.The most successful prepared formulation was $\left(F_{3}\right)$ which consists of chlorpyrifos $48 \%+$ Calcium dodecyl benzene sulfonate (CaDBS) 3\% + Triton X-100 2\% with $<0.05 \mathrm{ml}$ in both hard and soft water. While the ml separation in the commercial formulation of chlorpyrifos was $0.1 \mathrm{ml}$ in hard water and $0.2 \mathrm{ml}$ in soft water.
\end{abstract}

The cream separation in emulsion stability test of prepared formulation of lambda-cyhalothrin was not observed after $1 \mathrm{hr}$ in both hard and soft water for lambda-cyhalothrin $\mathbf{5 \%}+$ dodecyl benzene sulfonate (CaDBS) $1.8 \%$ + Triton $\mathrm{X}-1003.2 \%\left(\mathrm{~F}_{1}\right)$ so it was the most successful prepared formulation compared to $0.9 \mathrm{ml}$ in hard water and $0 \mathrm{ml}$ in soft water in the second formulation which consists of lambda-cyhalothrin $5 \%+$ dodecyl benzene sulfonate (CaDBS) $2 \%+$ Triton X-100 $3 \%\left(F_{2}\right)$. While the $\mathrm{ml}$ separation in the commercial formulation of lambda-cyhalothrin was $0.4 \mathrm{ml}$ cream +0.3 $\mathrm{ml}$ oil in hard water and $0.7 \mathrm{ml}$ cream $+0.2 \mathrm{ml}$ oil in soft water. The most successful formulations were tested against susceptible and field strains of Spodoptera littoralis (Boisd.).

The efficiency of the two prepared formulations were determined; in comparison with the standard

\footnotetext{
${ }^{1}$ Plant Protection Dept., Faculty of Agric. (Saba Basha), Alex. Univ.

${ }^{2}$ Plant Protection Dept., Faculty of Agric.,Zagazig Univ.

${ }^{3}$ Pesticides Formulation Dept.,Central Agric. Pestic. Lab (CAPL),

${ }^{4}$ Plant Protection Res. Instit.,Agric. Res. Center, El-Sabheia, Alex.

Received February 28, 2016, Accepted March 28, 2016
}

(commercial) formulations of chlorpyrifos-ethyl and lambda-cyhalothrin respectively, against the susceptible and field strains of $\boldsymbol{S}$. littoralis (Boisd.). Also, the effect of adding the synergist $\left(\right.$ Sylgard $309^{\circledR}$ ) to each treatment was determined.

In the susceptible strain after 48 hours bioassay; $L C_{50}$ value for the prepared formulation of chlorpyrifos was10.12 ppm and after adding Sylgard $309^{\circledR}$ the result was found to be $7.14 \mathrm{ppm}$, while $\mathrm{LC}_{50}$ values for its commercial formulation alone and/or with Sylgard $309^{\circledR}$ were 13.74 and $9.61 \mathrm{ppm}$, respectively. $L C_{50}$ value for the prepared formulation of lambda-cyhalothrin was 85.70 ppm; after adding Sylgard $309^{\circledR}$ became $68.34 \mathrm{ppm}$, while $\mathbf{L C}_{50}$ for the commercial formulation of lambdacyhalothrin alone and/or with Sylgard $309^{\circledR}$ were 152.54 and $108.52 \mathrm{ppm}$, respectively.

In the field strain after 48 hours bioassay; $L_{50}$ value for the prepared formulation of chlorpyrifos was 17.89 ppm, but with the addition of Sylgard $309^{\circledR}$ the result showed a magnificent effect as of $13.77 \mathrm{ppm}$. For its commercial formulation only and/or in addition to Sylgard $309^{\circledR} \mathrm{LC}_{50}$ values were found to be 163.19 and $154.28 \mathrm{ppm}$ respectively. $\mathrm{LC}_{50}$ value for the prepared formulation of lambda-cyhalothrin was $1212.62 \mathrm{ppm}$; with the addition of Sylgard $309^{\circledR}$ was slightly decreased to $1208.23 \mathrm{ppm}$, while $\mathbf{L C}_{50}$ values for the commercial formulation only and/or in addition to Sylgard $309^{\circledR}$ were 1925.87 and 1914.77 ppm, respectively.

The calculation of Resistance Factor (RF) after 48 hours bioassay revealed that the field strain compared to the susceptible one of $S$. littoralis showed a real case of resistance to both of the commercial formulations of chlorpyrifos and lambda-cyhalothrin while the prepared formulations of each showed either the natural tolerance or the vigor tolerance case, in respect.

Keywords: Pesticide formulation - chlorpyrifos-ethyl lambda-cyhalothrin - Spodoptera littoralis.

\section{INTRODUCTION}

Pesticide formulation is the process of transforming the active ingredient molecule to a product, which can be applied by practical methods to control pests in safe and at economical use (UNIDO, 1983).

Chlorpyrifos is a broad-spectrum organophosphorus insecticide, used for controlling cotton leafworm, 
aphids, whiteflies, roundworms, termites, mosquitos, flies, various crop pests in soil and on foliage, household pests and aquatic larvae. It is used as a soil treatment (pre-plant and at planting) (Pradeep et al., 2012).

Lambda-cyhalothrin is a synthetic pyrethroid insecticide and is being used to control a variety of pests on different crops and also household and public health insect pests. Pests controlled on different crops include Lepidopteran larvae, Coleopteran larvae and adults, aphids, Colorado beetles and thrips. Crops on which it is usually applied are cotton, cereals, hops, ornamentals, potatoes, vegetables or others. It may also be used for structural pest management directed to public health for controlling insects such as cockroaches, mosquitoes, ticks, fleas and flies.

The cotton leafworm, S. littoralis (Boisd.) is a polyphagous, foliage feeding insect that is distributed throughout the world. This insect is one of the major cotton pests that causes considerable damage to many important vegetables and field crops (Shonouda and Osmam, 2000; Magd El-Din and El- Gengaihi, 2000; El-Khawas and Abd El-Gawad, 2002).

The objective of the present study was subjected to prepare new formulations ofchlorpyrifos-ethyl and lambda-cyhalothrin; and assay the successful formulations against the $4^{\text {th }}$ larval instar of susceptible and field strains of cotton leafworm, S. litraltois (Boisd.) under laboratory conditions.

\section{MATERIALS AND METHODS}

The adopted study was carried out to prepare and evaluate emulsifiable concentrate formulations for both chlorpyrifos-ethyl and lambda-cyhalothrin. The prepared formulations were subjected to WHO specification tests. The successful prepared formulations were assayed against both the susceptible and field strains of Spodoptera littoralis in comparison to the commercial formulations.

\section{Formulating the selected pesticides}

\section{a.Formulation preparations and the Standard (Commercial)}

Different combinations of each technical insecticide were prepared using the solvent (Xylene) with the emulsifiers (Ca DBS) + Triton X-100 then the most stable and successful formulations were chose through a series of physical and chemical tests. Two commercial ready-use formulations for each selected insecticides were subjected for comparison with the prepared formulations.

\section{b. Solvent and emulsifiers}

Xylene, as a solvent was used for formulating the E.C. of both chlorpyrifos-ethyl and lambda-cyhalothrin. Two formulations of each insecticide were prepared using the emulsifiers calcium dodecyl benzene sulfonate (Ca DBS) $60 \%$ in butanol as an anionic liquids and Triton X-100 as a non anionic liquid.

\section{Physico-chemical properties of standard (commercial) and prepared formulations}

In a laboratory study, the physico-chemical properties of tested standard (commercial formulations) and prepared formulations of the two selected insecticides (chlorpyrifos-ethyl and lambda-cyhalothrin) were investigated to select the more stable and successful formulations.

\section{a. Emulsion Stability Tests \\ 1. Standard hard and soft water}

Hard and soft water were prepared according to the method of (WHO Specifications, 1973). Hard water was prepared by dissolving $0.304 \mathrm{~g}$ of calcium chloride (anhydrous) and $0.139 \mathrm{~g}$ of magnesium chloride hexahydrate in distilled water and made up to 1 liter. This provides water with a hardness of 342 parts per million (ppm), calculated as calcium carbonate.

Soft water was also prepared by mixing one part of the previous hard water with nine parts of distilled water. This provides water with a hardness of $34.2 \mathrm{ppm}$, calculated as calcium carbonate.

\section{Testing the emulsion stability}

Emulsion stability was determined according to the method of (WHO Specification, 1973), where 75-80 ml of water (hard WHO or distilled) was poured into a 250 $\mathrm{ml}$ beaker having an internal diameter of $6.5 \mathrm{~cm}$ and a $100 \mathrm{ml}$ calibration mark. The beaker was settled in a water bath at a temperature of $30^{\circ} \mathrm{C} \pm 1^{\circ} \mathrm{C}$. Five milliliters $(5 \mathrm{ml})$ of the concentrate was added, while stirring with a glass rod (4-6 $\mathrm{mm}$ in diameter), at about four revolutions per second. The concentrate was added to the water at the rate of $25-30 \mathrm{ml}$ per minute, with the point of the pipette $(2 \mathrm{ml})$. Inside the beaker, the flow of the concentrate was directed towards the centre and not against the side of the beaker. The water was added to make up to $100 \mathrm{ml}$. The water was stirred continuously, and immediately was poured into a clean dry $100 \mathrm{ml}$ graduated cylinder. The stirring time was 3 minutes from the beginning of the addition of the concentrate until the emulsion was poured into $100 \mathrm{ml}$ cylinder.

The cylinders were kept in a water bath at $29-31^{\circ} \mathrm{C}$ for an hour and any creaming or separation was examined and recorded. 


\section{b. Determination of Free Acidity and Alkalinity}

Free acidity and alkalinity for the used emulsifiers and both the standard (commercial) and prepared formulations were determined according to the method of (WHO specification, 1973).

\section{c. Viscosity and surface tension}

Viscosity was measured by the DigitalViscometer_Brookfield, Model: 1vdv e230 and the surface tension was measured by a stalagmometer (075922) Model: $2.5 \mathrm{ml}$

\section{d. Heat Stability test for successful emulsifiable concentrates}

Heat stability test for both the commercial and each of prepared emulsifiable concentrates was done using the method of (WHO specification, 1973) and tested for their emulsion stability.

III. The toxicity of the standard (commercial) and prepared formulations to Spodoptera littoralis.

The toxicity of the standard (commercial) and prepared formulations of both the used insecticides were evaluated against the cotton leafworm Spodoptera littoralis (Boisd.) (Lepidoptera: Noctuidea).

\section{a. Stock culture of tested strains of cotton leafworm \\ Spodoptera littoralis (Boisd.) (Lepidoptera: Noctuidea)}

Two strains (susceptible and field) of the Egyptian cotton leafworm S. littoralis were used in the present investigation. Susceptible strain egg-batches were obtained from the maintained stock culture at the rearing lab of the Plant Protection Dept., Faculty of Agric. (Saba Basha), Alex. Univ., while the field eggmasses were kindly supplied by the Research Lab., Syngenta Experimental Station at Kaha, Egypt.

Each of the newly hatched larvae of the susceptible and field strains were reared in the laboratory away from any insecticidal contamination at the department of plant protection, Faculty of Agriculture (Saba Basha), Alexandria under the constant higrothermic conditions: $27 \pm 1{ }^{\circ} \mathrm{C}$ and $70 \pm 5 \%$ R.H. to provide the used insects in the present investigation. The raised larvae were fed on leaves of castor bean oil, Ricinus communis in cylindrical glass jars (1 lb.) (El-Defrawi et al., 1964).

b. Bioassay of the tested insecticides against larvae of the cotton leafworm, Spodoptera littoralis (Boisd.):

Castor-bean leaves were dipped for 15 seconds in increased series of the standard or the prepared formulated insecticides that have been diluted with water. One hundred $\mathrm{ml}$ of the prepared diluted concentration in a glass beaker $(250 \mathrm{ml})$ were used to dip the leaves in. As the treated leaves were dried, 10 larvae of the $4^{\text {th }}$ instar were exposed to the treated leaves in glass beaker $(250 \mathrm{ml})$, covered with muslin texture. The mortality percentages of each of the tested concentrations were recorded after 24 and 48 hours as

exposure bioassay periods. Every concentration was replicated three times. The data were analyzed by the aid of a computer. The correction of mortality percentages, if there were any control mortality was done through a computer program "Probit" using Abbott's formula. Probit (mortality)/log con. (dose) regression equations, $\mathrm{LC}_{50}$ and $\mathrm{LC}_{95}$ 's and associated fiducial limits were calculated by the method described by Finney (1971).

\section{c. Synergistic action of the tested formulations with Sylgard 309 ${ }^{\circledR}$}

The joint action effect of the tested formulations of chlorpyrifos-ethyl and lambda-cyhalothrin with "Sylgard $309^{\circledR} "$ (as a synergist) was evaluated against the tested larvae of $S$. littoralis susceptible and field strains. The evaluation of the synergistic action, at different concentrations of each tested formulation were prepared as a final volume of $100 \mathrm{ml}$ containing $0.25 \mathrm{ml}$ of "Sylgard $309^{\circledR}$ ".

The castor leaves were dipped in each of these prepared concentrations; and after dryness they were offered to the $4^{\text {th }}$ instar larvae of the treated cotton leafworm. The data were recorded and probit (mortality)/log con. (dose) regression equations, $\mathrm{LC}_{50}$ and $\mathrm{LC}_{95}$ 's and associated fiducial limits were calculated by the method described by Finney (1971). The synergistic ratio was calculated as follows:

Synergistic ratio $=\frac{\text { LC50 for insecticide alone }}{\text { LC50 for insecticide }+ \text { synergist }}$

Synergistic ratio (SR) was used to categorize the results into three categories ( $\mathrm{SR}<1$ means antagonism [Antagonism], $\mathrm{SR}=1$ means addition [Addition] and SR $>1$ means synergism[S]).

\section{d. Statistical Analysis of bioassays data}

Probit (mortality)/log con. (Dose) regression equations were calculated using the maximum likelihood algorithm described by Finney (1971) adapted as a computer program (Tayeb, unpublished) $\mathrm{LC}_{50}$ and $\mathrm{LC}_{95}$ 's and associated fiducial limits were also calculated by the method described by Finney.

Resistance Factor $(\mathrm{RF})=\mathrm{LD}_{50}$ resistant strain (field strain)/LD $\mathrm{L}_{50}$ susceptible strain

Resistance Factor (RF) was used to categorize the results into three categories:

1- Natural Tolerance: $\mathrm{RF}=1-<2$

2- Vigor Tolerance: $\mathrm{RF}=2-9$ 
3- Resistance: $\mathrm{RF}=>9$

\section{RESULTS AND DISCUSSION}

I. Formulation of chlorpyrifos-ethyl and lambdacyhalothrin emulsifiable concentrates

\section{a. Chlorpyrifos formulations}

\section{Physical properties}

Several attempts were made for formulating chlorpyrifos EC $48 \%$. The prepared formulations were tested for their emulsion stability, acidity, alkalinity according to (WHO specifications, 1973), in addition to viscosity and surface tension. Chlorpyrifos (prepared and commercial) formulations and their physical properties are presented in Table (1).

The mixture of the technical chlorpyrifos with the emulsifier (Calcium Dodecyl benzene Sulfonate [Ca DBS]) as ionic liquid succeeded in inducing emulsion stability in the prepared formulations. TritonX-100 was found to enhance the stability of the prepared formulations. In this respect, (Mata-Sandoval et al., 2001) reported that Triton $X-100$ as a heterogeneous nonionic octylphenolethoxylate surfactant can be added to increase the apparent water solubility of hydrophobic organic compounds.

\section{Heat Stability}

Formulating certain insecticides such as chlorpyrifos to meet specific regulations or increasing their effectiveness to replace successful pesticide product (formulation) with another one of equivalent performance can be usually accepted.

Table(2) show the heat stability of the most successful prepared (F3) and the commercial emulsifiable concentrate (E.C.) formulations of chlorpyrifos $48 \%$.

\section{b. Lambda-cyhalothrin formulations}

\section{Physical properties}

The physical properties of the prepared lambdacyhalothrin formulations compared to the commercial one are shown in Table (3)

According to (WHO Specification, 1973), any separation, including creaming at the top or bottom of $100 \mathrm{ml}$ of emulsion should not exceed $2 \mathrm{ml}$.

Table 1. Physical properties of three prepared chlorpyrifos E.C Formulations $\left(F_{1}, F_{2}\right.$ and $F_{3}$ ) compared to the commercial formulations

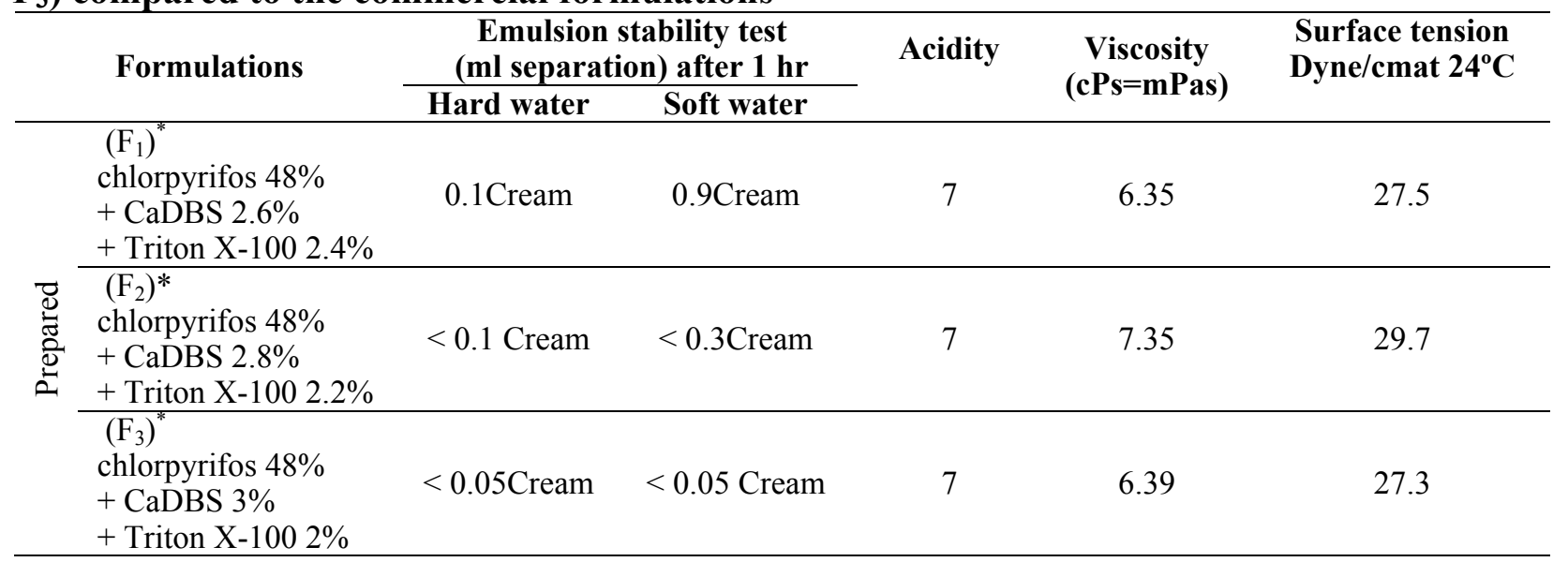

Chlorozan ${ }^{\circledR}$

0.1 Cream $\quad 0.2$ Cream

6.5

6.31

27.1

$* \mathrm{~F}_{1}=$ Formulation $1, \mathrm{~F}_{2}=$ Formulation 2 and $\mathrm{F}_{3}=$ Formulation 3

Table 2. Heat stability for chlorpyrifos formulations (EC 48\%)

\begin{tabular}{|c|c|c|c|}
\hline \multirow{2}{*}{\multicolumn{2}{|c|}{ Formulations }} & \multicolumn{2}{|c|}{$\begin{array}{c}\text { Heat stability } \\
(\mathrm{ml} \text { separation) after } 1 \mathrm{hr}\end{array}$} \\
\hline & & Hard water & Soft water \\
\hline Prepared & $\begin{array}{l}\left(\mathrm{F}_{3}\right)^{*} \text { chlorpyrifos } 48 \% \\
+ \text { CaDBS } 3 \% \\
+ \text { Triton X-100 2\% }\end{array}$ & $<0.1$ Cream & $<0.2$ Cream \\
\hline Commercial & Chlorozan $^{\circledR}$ & $<0.1$ Cream & 0.1 Cream \\
\hline
\end{tabular}


Table 3. Physical properties of two prepared lambda-cyhalothrin formulations compared to the commercial formulation

\begin{tabular}{|c|c|c|c|c|c|c|}
\hline \multirow{2}{*}{\multicolumn{2}{|c|}{ Formulations }} & \multicolumn{2}{|c|}{$\begin{array}{c}\text { Emulsion stability test } \\
\text { (ml separation) after } 1 \mathrm{hr}\end{array}$} & \multirow[t]{2}{*}{ Acidity } & \multirow{2}{*}{$\begin{array}{c}\text { Viscosity } \\
(\mathrm{cPs}=\mathrm{mPas})\end{array}$} & \multirow{2}{*}{$\begin{array}{c}\text { Surface tension } \\
\text { Dyne/cmat } \\
24^{\circ} \mathrm{C}\end{array}$} \\
\hline & & Hard water & Soft water & & & \\
\hline \multirow{2}{*}{ Prepared } & $\begin{array}{l}\left(\mathrm{F}_{1}\right)^{*} \\
\text { lambda-cyhalothrin } \\
5 \%+\text { CaDBS } 1.8 \%+ \\
\text { Triton X-100 3.2\% }\end{array}$ & 0 & - & 7 & 11.00 & 40.1 \\
\hline & $\begin{array}{l}\left(\mathrm{F}_{2}\right)^{*} \\
\text { lambda-cyhalothrin } \\
5 \%+\text { Ca DBS 2\%+ } \\
\text { Triton X-100 3\% }\end{array}$ & $\begin{array}{c}0.9 \\
\text { cream }\end{array}$ & 0 & 7 & 10.3 & 39.5 \\
\hline Commercial & Lambada $^{\circledR}$ & $\begin{array}{l}0.4 \text { Cream } \\
0.3 \text { Oil }\end{array}$ & $\begin{array}{l}0.7 \text { Cream } \\
0.2 \text { Oil }\end{array}$ & 6 & 10.00 & 38.5 \\
\hline
\end{tabular}

$* \mathrm{~F}_{1}=$ Formulation 1 and $\mathrm{F}_{2}=$ Formulation 2

\section{Heat stability}

The most successful prepared formulation $\left(\mathrm{F}_{1}\right)$ and commercial one were satisfactory and fulfilled the specified requirements, exhibited in table(4). They passed successfully the heat effect giving a separation range that was less than the maximum acceptable limits (2ml) (FAO Specification, 2013).

II. Toxicity of the commercial (standard) and prepared Formulations of chlorpryifos-ethyl and lambda-cyhalothrin against the larvae of cotton leafworm.

\section{a. Chlorpyrifos Formulations}

Both the prepared and the commercial formulations of chlorpyrifos $48 \%$ EC were evaluated against $4^{\text {th }}$ instar larvae of the susceptible and field strains of the cotton leafworm $S$. littoralis. It was found that the prepared formulation $\left(\mathrm{F}_{3}\right)$ was the most stable formulation and it was tested on the $4^{\text {th }}$ instar larvae in comparison with the commercial one.

The results in Table (5) show the response of susceptible (laboratory) and field strains of S. littoralis to the two tested formulations of chlorpyrifos after a bioassay time of $48 \mathrm{hrs}$. The prepared formulation $\left(\mathrm{F}_{3}\right)$ was the most effective formulation against the susceptible strain giving the lowest $\mathrm{LC}_{50}$ value of 10.12 ppm followed by the commercial one with $\mathrm{LC}_{50}$ value of $13.74 \mathrm{ppm}$.

In addition, this prepared formulation $\left(\mathrm{F}_{3}\right)$ was also the most effective against the treated $4^{\text {th }}$ instar larvae of the field strain giving a lower $\mathrm{LC}_{50}$ value of $17.89 \mathrm{ppm}$, followed by the commercial formulation $\left(\right.$ Chlorozan $^{\circledR}$ ) with $\mathrm{LC}_{50}$ value of $163.19 \mathrm{ppm}$ after a $48 \mathrm{hrs}$ bioassay.

The calculation of the resistance factor revealed that the prepared formulation showed lower resistance factor of 1.77 fold (based on $\mathrm{LC}_{50}$ values) and/or 1.31 fold (based on $\mathrm{LC}_{95}$ values); while the resistance factor of commercial formulation 11.88 fold (based on $\mathrm{LC}_{50}$ values) and/or 4.06 fold (based on $\mathrm{LC}_{95}$ values). The detected value of resistance factor of the commercial formulation showed a real case of resistance after 48 hours (based on $\mathrm{LC}_{50}$ values), while the prepared formulation showed a case of natural tolerance.

Generally, the prepared formulation $\mathrm{F}_{3}$ performed better than the commercial one $\left(\right.$ Chlorozan $\left.^{\circledR}\right)$ when they were tested against $4^{\text {th }}$ instar larvae of $S$. littoralis.

\section{b. Lambda-cyhalothrin Formulations}

Two formulations of emulsifiable concentrates (ECs) of lambda-cyhalothrin 5\% were also evaluated against the two used strains of $S$. littoralis. Response of both strains to the different tested formulations after 48 hrs bioassay is presented in table (6).

The data show that the prepared formulation $\left(\mathrm{F}_{1}\right)$ was proved to be the most effective tested formulation against the susceptible larvae recording a lower $\mathrm{LC}_{50}$ value of $137.98 \mathrm{ppm}$, followed by Lambada ${ }^{\circledR}$ (152.54 ppm).

Moreover, evaluation of the tested formulations against the field strain larvae, the $48 \mathrm{hrs}$ bioassay showed that the prepared formulation $\left(\mathrm{F}_{1}\right)$ was also the most effective tested one with the lowest $\mathrm{LC}_{50}$ value of 1212.62 ppm, followed by Lambada ${ }^{\circledR}(1925.87 \mathrm{ppm})$.

The resistance factor of the tested field strains, compared with the susceptible one pronounced a case of vigor tolerance of the field strain, compared to the susceptible strain since that factor reached 8.79 fold when testing the prepared formulation $\left(\mathrm{F}_{1}\right)$ (based on $\mathrm{LC}_{50}$ value) and 2.05 fold (based on $\mathrm{LC}_{95}$ value); otherwise, the calculated resistance factor for the commercial formulation was 12.63 fold (based on $\mathrm{LC}_{50}$ value) and 2.91 fold (based on $\mathrm{LC}_{95}$ value). There was a real case of resistance in the field strain when the commercial formulation is used. 
Table 4. Heat stability for emulsifiable concentrate (E.C) formulations of lambdacyhalothrin 5\%

\begin{tabular}{|c|c|c|c|}
\hline & \multirow[t]{2}{*}{ Formulations } & \multicolumn{2}{|c|}{$\begin{array}{c}\text { Heat stability } \\
(\mathrm{ml} \text { separation) after } 1 \mathrm{hr}\end{array}$} \\
\hline & & Hard water & Soft water \\
\hline Prepared & $\begin{array}{c}\left(\mathrm{F}_{1}\right)^{*} \\
\text { lambda-cyhalothrin 5\%+ } \\
\text { CaDBS1.8\% +Triton X-100 3.2\% }\end{array}$ & 0 & 0 \\
\hline Commercial & Lambada $^{\circledR}$ & $<0.05$ Cream & $\begin{array}{l}0.3 \text { Cream } \\
0.1 \text { Oil }\end{array}$ \\
\hline
\end{tabular}

Table 5. Response of susceptible and field strains of $\boldsymbol{S}$. littoralis to the tested formulations of chlorpyrifos after 48 hours bioassay.

\begin{tabular}{|c|c|c|c|c|c|c|c|}
\hline 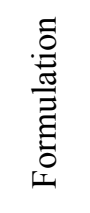 & $\begin{array}{c}\mathbf{L C}_{\mathbf{5 0}} \\
\text { Susceptible } \\
\text { [Field strain] } \\
(\mathbf{p p m})\end{array}$ & $\begin{array}{l}\text { Fiducial limits } \\
\text { Lower- Upper }\end{array}$ & $\begin{array}{c}\mathbf{L C}_{95} \\
\text { Susceptible } \\
\text { [Field } \\
\text { strain] } \\
\text { (ppm) }\end{array}$ & $\begin{array}{c}\text { Fiducial } \\
\text { limits } \\
\text { Lower- } \\
\text { Upper }\end{array}$ & Slope \pm SE & $\boldsymbol{P}$ & $\begin{array}{c}\text { Resistance } \\
\text { factors } \\
\text { (LC }_{50}, \mathbf{L C}_{95}\end{array}$ \\
\hline \multirow{2}{*}{ 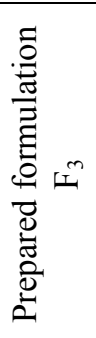 } & 10.12 & 7.73-13.19 & 48.12 & $26.32-90.16$ & $2.43 \pm 0.27$ & 0.96 & \\
\hline & [17.89] & [14.67-21.79] & {$[63.10]$} & [42.77-93.82] & $3.01 \pm 0.24$ & 0.70 & $1.77,1.31$ \\
\hline \multirow{2}{*}{ 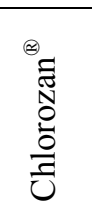 } & 13.74 & $11.06-17.08$ & 49.23 & $25.88-95.27$ & $2.97 \pm 0.52$ & 0.91 & \\
\hline & [163.19] & [158.84-167.65] & [199.74] & $\begin{array}{l}{[185.68-} \\
214.87]\end{array}$ & $18.74 \pm 9.91$ & 0.99 & $11.88,4.06$ \\
\hline
\end{tabular}

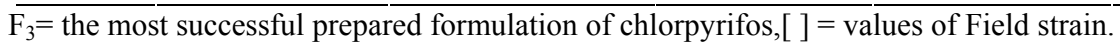

Table 6. Response of susceptible and field strain of $\boldsymbol{S}$. littoralis to different formulations of lambda-cyhalothrin after 48 hours bioassay

\begin{tabular}{|c|c|c|c|c|c|c|c|}
\hline Formulation & $\begin{array}{c}\mathbf{L C}_{50} \\
\text { Susceptible } \\
\text { [Field } \\
\text { strain] } \\
\text { (ppm) } \\
\end{array}$ & $\begin{array}{l}\text { Fiducial } \\
\text { limits } \\
\text { Lower- } \\
\text { Upper }\end{array}$ & $\begin{array}{c}\mathbf{L C}_{95} \\
\text { Susceptible } \\
\text { [Field } \\
\text { strain] } \\
\text { (ppm) } \\
\end{array}$ & $\begin{array}{l}\text { Fiducial } \\
\text { limits } \\
\text { Lower- } \\
\text { Upper }\end{array}$ & Slope \pm SE & $P$ & $\begin{array}{c}\text { Resistance } \\
\text { factors } \\
\left(\mathrm{LC}_{\mathbf{5 0}}, \mathrm{LC}_{\mathbf{9 5}}\right.\end{array}$ \\
\hline \multirow{2}{*}{$\begin{array}{l}\text { Prepared } \\
\text { formulation } \\
\mathrm{F}_{1}\end{array}$} & 137.98 & $\begin{array}{c}106.34- \\
179.23 \\
\end{array}$ & 605.57 & $\begin{array}{l}228.26- \\
1619.46 \\
\end{array}$ & $2.56 \pm 0.53$ & 0.94 & \multirow{2}{*}{$8.79,2.05$} \\
\hline & [1212.62] & $\begin{array}{c}{[1207.92-} \\
1217.35]\end{array}$ & [1243.46] & $\begin{array}{c}{[1234.87-} \\
1252.11]\end{array}$ & $\begin{array}{c}150.83 \pm \\
568.57\end{array}$ & 0.99 & \\
\hline \multirow{2}{*}{ Lambada $^{\circledR}$} & 152.54 & $\begin{array}{c}118.41- \\
196.68\end{array}$ & 679.36 & $\begin{array}{l}274.61- \\
1693.73 \\
\end{array}$ & $2.54 \pm 0.45$ & 0.81 & \multirow{2}{*}{$12.63,2.91$} \\
\hline & [1925.87] & $\begin{array}{c}{[1917.93-} \\
1933.85]\end{array}$ & [1973.97] & $\begin{array}{c}{[1948.64-} \\
1999.62]\end{array}$ & $\begin{array}{l}153.56 \pm \\
1466.20 \\
\end{array}$ & 0.99 & \\
\hline
\end{tabular}

$\overline{\mathrm{F}_{1}=\text { the most successful prepared formulation of lambda-cyhalothrin, }[]}=$ values of Field strain. 


\section{Synergistic effect of Sylgard $309^{\circledR}$ with the all tested formulations of chlorpyrifos and lambda- cyhalothrin against the tested strains of the cotton leafworm $S$. littoralis}

Synergists are chemicals that, while not possessing inherent pesticidal activity, nonetheless promote or enhance the effectiveness of other pesticides when combined. They enhance another active ingredient's ability to kill the pest while using the minimum amount of active ingredient, but do not themselves possess pesticidal properties.

Synergists are among the most straight forward tools for overcoming metabolic resistance, because they can directly inhibit the resistance mechanism itself. Since the first demonstration of insecticide synergism over 40 years ago (Eagleson, 1940), their effective application against agricultural pests has offered tremendous promise but achieved little utility.

Sylgard $309^{\circledR}$ as a synergist was used at a rate of $0.25 \%$ diluted in water that has been used for preparation of the serial dilutions (concentrations) of tested formulations (prepared and commercial). Different concentrations of each prepared and commercial formulations of either chlorpyrifos or lambda-cyhalothrin + Sylgard $(0.25 \%)$ were bioassayed for $48 \mathrm{hrs}$ against both tested strains of the cotton leafworm S. littoralis.

\section{a. Chlorpyrifos formulations}

Table (7) show the detected synergistic effect of each of the prepared or commercial formulation of chlorpyrifos with Sylgard $309^{\circledR}$ (a synergist) compared with the commercial formulation alone against larvae of field and susceptible strains of $S$. littoralis after 48 hours bioassays.

The results revealed that the addition of Sylgard $309^{\circledR}$ to the prepared and/or commercial formulations caused a synergistic effect enhancing the toxicity of these evaluated formulations against the $4^{\text {th }}$ instar larvae of both the susceptible and field strains when they were assessed for 48 hours. The obtained results can lead to a reduction of the recommended field doses which in turn reduce the costs of application and minimize the environmental pollution.

It was also found that the addition of Sylgard $309^{\circledR}$ at a rate of $0.25 \%$ to chlorpyrifos prepared and commercial formulations pronounced a synergistic effect against the $4^{\text {th }}$ instar larvae of both tested strains after feeding on treated castor leaves for a period of 48 hours.

In the susceptible strain; the prepared formulation $\mathrm{LC}_{50}$ value was $10.12 \mathrm{ppm}$ while after adding Sylgard
$309^{\circledR}$ it was $7.14 \mathrm{ppm}$. On the other hand the $\mathrm{LC}_{50}$ values of the commercial formulation alone and/or after adding Sylgard $309^{\circledR}$ were 13.74 and $9.61 \mathrm{ppm}$, respectively.

While, in the field strain, the $\mathrm{LC}_{50}$ value of the prepared formulation $\left(\mathrm{F}_{3}\right)$ was $17.89 \mathrm{ppm}$ and after adding Sylgard $309^{\circledR}$ it was $13.77 \mathrm{ppm}$, also the $\mathrm{LC}_{50}$ values of the commercial formulation alone and after adding Sylgard $309^{\circledR}$ were 163.19 and 154.28 ppm, respectively.

The data in table (7) also show that the synergistic ratio after $48 \mathrm{hrs}$ for each case of adding the synergist to chlorpyrifos prepared and commercial formulations was $(>1)$ expressing the synergistic action. The synergistic ratio in the susceptible strain was 1.42 for the prepared formulation and 1.43 for the commercial one. While in the field strain it was 1.30 and 1.06 for the prepared and commercial formulations, in respect.

There is a possibility of using Sylgard $309^{\circledR}$ as a synergist with chlorpyrifos formulations that could be used for controlling $S$. littoralis. It could be also recommended that Sylgard $309^{\circledR}$ would be useful for chlorpyrifos formulations. In this respect, (Abd-Ellah, 2009) found that sesame seed extract (2\%) with chlorpyrifos -methyl showed synergism against the $4^{\text {th }}$ larval instar of $S$. littoralis. This might be due to the effect of sesame seed extract on the mixed function oxidase system of microsome (MFO), which is responsible for detoxification process of chlorpyrifos (Sun and Johnson, 1960), while Sylgard 309 ${ }^{\circledR}$ hasn't such effect. Also, (Georghiou et al., 1975) stated that the toxicity of organophosphorous compound was not synergized by pipreonyl butoxide; (Philip, 1995) reported that the addition of Sylgard ${ }^{\circledR}$ to Cymbuch $^{\circledR}$ or Guthion $^{\circledR}$ did not improve the control of Colorado potato beetle.

\section{b. Lambda-cyhalothrin formulations}

The data in Table (8) elucidate that the synergistic ratio after $48 \mathrm{hrs}$ for each case of adding with either lambda-cyhalothrin prepared $\left(\mathrm{F}_{1}\right)$ or commercial formulations was $(>1)$ expressing the synergistic action. In the susceptible strain; the prepared formulation $\mathrm{LC}_{50}$ value was $85.70 \mathrm{ppm}$, while after adding Sylgard $309^{\circledR}$ it was $68.34 \mathrm{ppm}$. In this concern the $\mathrm{LC}_{50}$ values of the commercial formulation alone and after adding Sylgard $309^{\circledR}$ were 152.54 and $108.52 \mathrm{ppm}$, respectively.

While in the field strain, the $\mathrm{LC}_{50}$ value of the prepared formulation $\left(\mathrm{F}_{1}\right)$ was $1212.62 \mathrm{ppm}$ and after adding Sylgard $309^{\circledR}$ it was 1208.23 ppm, also the $\mathrm{LC}_{50}$ values of the commercial formulation alone and after adding Sylgard $309^{\circledR}$ were 1925.87 and 1914.77 ppm, respectively. 
Table 7. Synergistic effect of the prepared and commercial formulations of chlorpyrifos with Sylgard $309^{\circledR}$ against field and susceptible strains of $S$. littoralis after 48 hours bioassay

\begin{tabular}{|c|c|c|c|c|}
\hline Formulation & $\begin{array}{c}\mathbf{L C}_{50}(\mathbf{p p m}) \\
\text { Susceptible } \\
\text { [Field strain]* }\end{array}$ & $\begin{array}{c}\text { Fiducial limits } \\
\text { (Lower- Upper) } \\
\text { Susceptible[Field strain] }\end{array}$ & $\begin{array}{l}\text { Synergistic Ratio } \\
\text { Susceptible } \\
\text { [Field strain] }\end{array}$ & $\begin{array}{c}\text { Status of } \\
\text { Synergism } \\
\text { Susceptible } \\
\text { [Field strain] }\end{array}$ \\
\hline Prepared & 10.12 & $7.73-13.19$ & \multirow{4}{*}{$\begin{array}{c}1.42 \\
{[1.30]}\end{array}$} & \multirow{4}{*}{$\begin{array}{c}\mathrm{S}^{* *} \\
{[\mathrm{~S}]^{* *}}\end{array}$} \\
\hline formulation $\mathrm{F}_{3}$ & [17.89] & [14.67-21.79] & & \\
\hline \multirow{2}{*}{$\mathrm{F}_{3}+\mathrm{S}$} & 7.14 & $5.13-9.83$ & & \\
\hline & [13.77] & {$[11.23-16.84]$} & & \\
\hline \multirow{2}{*}{ Chlorozan $^{\circledR}$} & 13.74 & $11.06-17.08$ & \multirow{4}{*}{$\begin{array}{c}1.43 \\
{[1.06]}\end{array}$} & \multirow{4}{*}{$\begin{array}{c}\mathrm{S}^{* *} \\
{[\mathrm{~S}]^{* *}}\end{array}$} \\
\hline & [163.19] & [158.84-167.65] & & \\
\hline \multirow{2}{*}{ Chlorozan $^{\circledR}+\mathrm{S}$} & 9.61 & 7.96-11.58 & & \\
\hline & {$[154.28]$} & {$[150.52-158.14]$} & & \\
\hline
\end{tabular}

Table 8. Synergistic effect of the prepared and commercial formulations of lambdacyhalothrin with Sylgard $309^{\circledR}$ against field and susceptible strains of $S$. littoralis after 48 hours bioassay

\begin{tabular}{|c|c|c|c|c|}
\hline Formulation & $\begin{array}{c}\mathbf{L C}_{50}(\mathbf{p p m}) \\
\text { Susceptible } \\
\text { [Field strain]* }\end{array}$ & $\begin{array}{c}\text { Fiducial limits } \\
\text { (Lower- Upper) } \\
\text { Susceptible [Field strain] }\end{array}$ & $\begin{array}{l}\text { Synergistic Ratio } \\
\text { Susceptible } \\
\text { [Field strain] }\end{array}$ & $\begin{array}{c}\text { Status of } \\
\text { Synergism } \\
\text { Susceptible } \\
\text { [Field strain] }\end{array}$ \\
\hline \multirow{2}{*}{$\begin{array}{l}\text { Prepared } \\
\text { formulation } \mathrm{F}_{1}\end{array}$} & 85.70 & $71.70-102.39$ & \multirow{4}{*}{$\begin{array}{c}1.25 \\
{[1.004]}\end{array}$} & \multirow{4}{*}{$\begin{array}{c}\mathrm{S}^{* *} \\
{[\mathrm{~S}]^{* *}}\end{array}$} \\
\hline & [1212.62] & [1207.92-1217.35] & & \\
\hline \multirow{2}{*}{$\mathrm{F}_{1}+\mathrm{S}$} & 68.34 & $54.59-85.48$ & & \\
\hline & {$[1208.23]$} & [1202.89-1213.61] & & \\
\hline \multirow{2}{*}{ Lambada $^{\circledR}$} & 152.54 & 118.41-196.68 & \multirow{4}{*}{$\begin{array}{c}1.41 \\
{[1.01]}\end{array}$} & \multirow{4}{*}{$\begin{array}{c}\mathrm{S}^{* *} \\
{[\mathrm{~S}]^{* *}}\end{array}$} \\
\hline & [1925.87] & [1917.93-1933.85] & & \\
\hline \multirow{2}{*}{ Lambada $^{\circledR}+\mathrm{S}$} & 108.52 & $91.31-128.96$ & & \\
\hline & [1914.77] & [1908.49-1921.07] & & \\
\hline
\end{tabular}

$\overline{\left(\mathrm{S}=\text { Sylgard } 309^{(\mathbb{R}},[]^{*}\right.}=$ values of Field strain, $\mathrm{S} * *=$ Synergism $)$

The synergistic ratio in the susceptible strain was 1.25 for the prepared formulation and 1.41 for the commercial one. But in the field strain it was 1.004 for the prepared formulation and 1.01 for the commercial one.

\section{REFERENCES}

Abd-Ellah, Mona M. G. 2009. Comparative studies on the biochemical mechanisms of action of certain modern insecticides. M. Sc. Thesis, Fac. Agric., Suez Canal Univ., Egypt.

Abbott, W. S. 1925. A method of computing the effectiveness of an insecticide. J. Econ. Entomol., 18: 265-267.

Eagleson, C. 1940. Oil Synergists for insecticides.U. S. Patent Office 2,202,145 (28 may, patented).

El-Defrawi, M. E., A. Toppozada, N. Mansour and M. Zeid 1964.Toxicological studies on the Egyptian cotton leafworm, Prodenialitura F. I. susceptibility of different larval instars of Prodenia to insecticides1. J. Econ. Entomol., 57: 591-593.
El-Khawas, M. A. M. and H. A. S. Abd El-Gawad 2002. The efficiency of two plant extracts (Fenugreek and Lupine) and commercial biofungicide (Biofly) ${ }^{\circledR}$ on the cotton leafworm, Spodoptera littoralis(Boisd.) (Lepidoptera: Noctuidae) larvae as a new approach of control. J. Egypt. Ger. Soc. Zool., 37: 39-57.

FAO 2013. FAO specifications and evaluations for agricultural pesticides. Food and Agriculture Organization of the United Nations, Rome.

Finney, D. J. 1971. Probit Analysis, $3^{\text {rd }}$ Edition, Cambridge Universitry Press, Cambridge, Uk, pp 333.

Georghiou, G. P., V. Ariaratram, M. E. Pasternak and C. S. Lin 1975. Organophosphorous multi-resistance of Culex pipiens quinquefaciatus in California. J.Econ. Entomol., 68(4): 461-467.

Magd El-Din, M. andS. E. El-Gengaihi 2000. Joint action of some botanical extracts against the Egyptian cotton leafworm, Spodoptera littoralis (Boisd.) (Lepidoptera: Noctuidae). Egypt, J. Biol. P. Cont., 10: 51-56. 
Mata-Sandoval, J.C., J. Karns and A. Torrents 2001. Influence of Rhamnolipids and Triton X-100 on the biodegradation of three pesticides in aqueous phase and soil slurries. J. Agric. Food Chem., 49 (7): 3296-3303.

Philip, H. G. 1995. Effect of various rates and combinatiuons of insecticides and adjuvants on the control of Colorado potato beetle.1994 Pest Management Research Report. The Expert Committee on Integrated Pest Management. Imformation and Planning Services Research Branch, Agricultrure and Agri-Food Canada. Ottawa, Ontario, Canada.

Pradeep, T., A. Ashokreddy, B. R. Buergi, A. Chainani, J. Chakrabarti, S. K. Das, N. Dasgupta, P. A. Joy, M. A. H. Muhammed, G. U. Kulkarni, K. Manzoor, R. Mukhopadhyay, A. S. Nair, T. Pal, S. K. Pati, G. V. P. Kumar, V. K. Pillai, E. Prasad, R. Philip, V. R. R. Kumar, P. R. Sajanlal, A. K. Samal, E. S. Shibu, T. S. Sreeprasad and C. Vijayan 2012.A Textbook of Nanoscience and Nanotechnology. Tata McGraw Hill Education Private Limited, New Delhi. P. 877.
Shonouda, M. L. andS. L. Osman 2000. New botanical derivatives, used in medicinal reparations, showing bioactive action on insect pests.1- Toxicological effect on the development of Spodoptera littoralis (Boisduval) (Lepidoptera: Noctuidae). J. Egypt. Ger. Soc. Zool., 31: 227-234.

Sun, Y. P. and E. R. Johnson 1960. Synergistic and antagonistic action of insecticides-synergist combinations, and their mode of action.J. Agric. Food Chem., 8:261 266.

UNIDO 1983. Formulation of pesticides in developing countries.

(C.F.)http://pdf.usaid.gov/pdf_docs/PNAAQ247.

WHO Specifications 1973. Specification of pesticides used in public health. $4^{\text {th }}$ edition, World Health Organization, Geneva, Switzerland.

\section{الملإص العرب \\ "تجهيز المبيدلت كعللم ألسلسي مؤثر علي كهاءة الكلوريرفوس اليثل والمبادلسبهالوثرين ضد دوة \\ Spodoptera littoralis (Boisd.) ورق التغلن}

عبد الفتاحسيد عبد الكريمسعد، للسيد هسن محمد تايب، لحمد اللسيد محمد عمر، اللسيدمجي الين فورج،

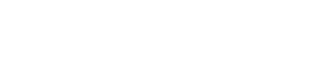

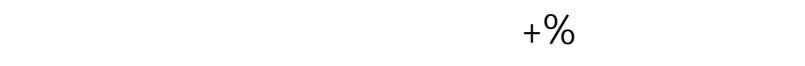

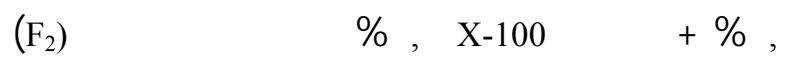

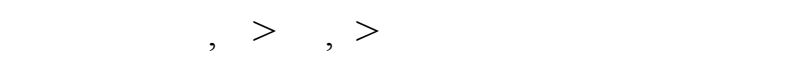
العسر واليسر علي التوالي والتي تتكون من كلوربيريفوس

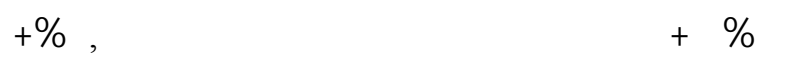

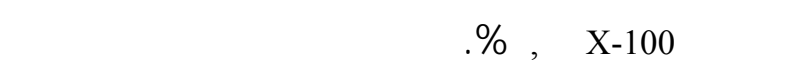

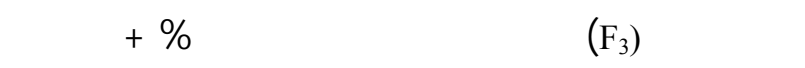

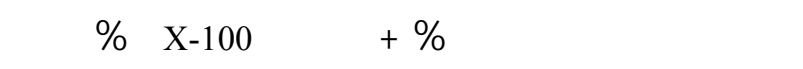

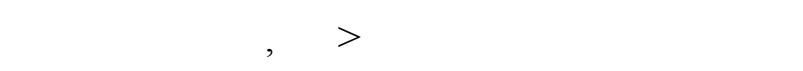

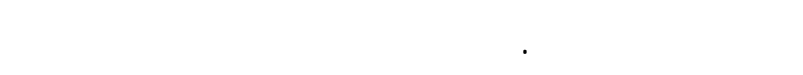

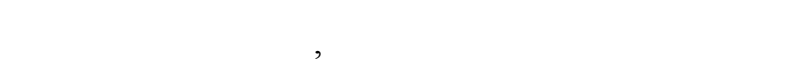
وr, · مل في الماء اليسر.

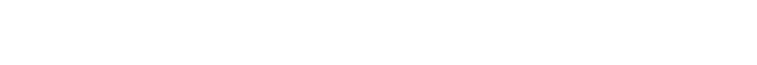

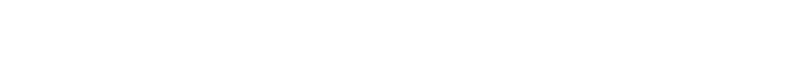

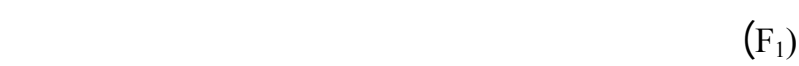

التجهيز ممطلح يستخدم في مختلف الظبيقات ومعنه

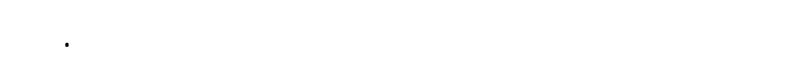

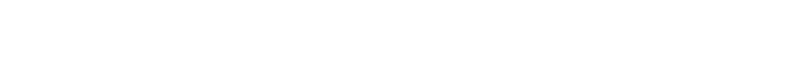
الكلوربيريفوس اليثل ولمبادا سيهالوثرين في ششل تجهيزة المئي مركز قابل للمستحلاب EC للاختبارات الكيميائية التابعة لمظمة الصحة العالمية WHO لالكتشف أي التجهيزات مابق للمواصفات، حيث مق تقدير الخصائص الكيميائية والفيزيائية الكل من التجهيزة التجارية والمعملية للك لل مبيد(لختبار ثبات المستحلب -الحموضة والقلوية - اللزوجة التوتر اللططي).

تشير نتائج لختبار شبلت المستحلب أن حجم الفصل

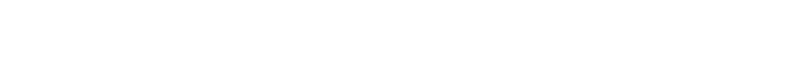

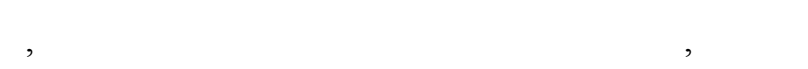

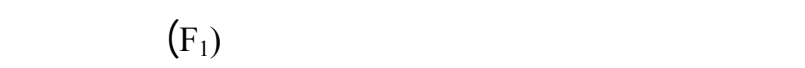




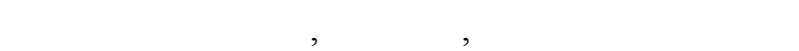
علي التوالي.

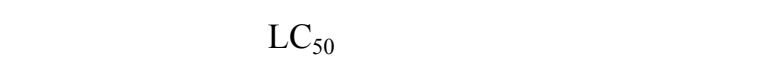

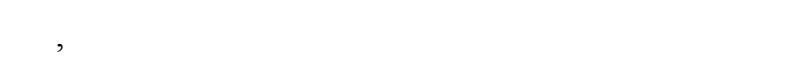
جزء في المليون وبعد الضفة المنشط كالت النتيجة Ir,VV

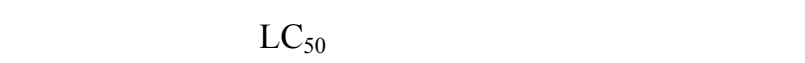

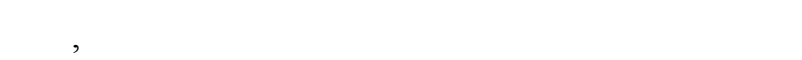

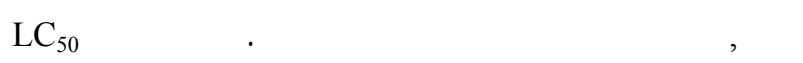

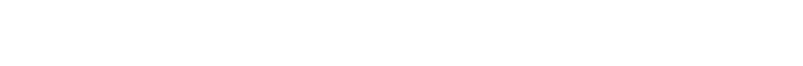
r,7r,

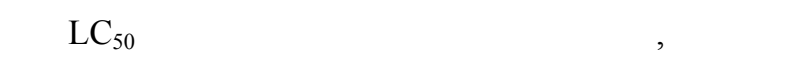
التجهيزة التجارية من لمبادا سيهالوثرين بمفردها وبعد

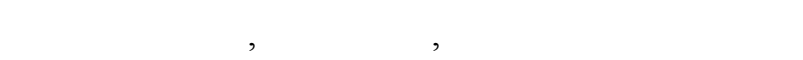
المليون علي التوالمي. لظٔهرت هسابلت معلمل المقاومة وجود حالة مقاومة هقيقية في للسلالة الدقلية من دوة ورق التطن مقارنة بللسلالة المعملية الحسلسة للتجهيزة التجارية للكلوربيريفوس

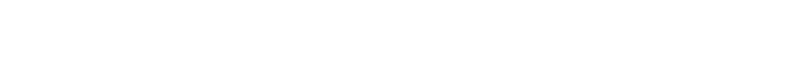
معمليا لظٔلرت تحمل طبيعي في اللسلالة الحقلية مقارنة

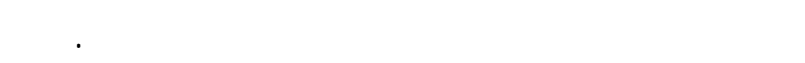
جانب لخر أظلهر معلمل المقاومة وجود حالة مقاومة حقيقية في للسلالة الحقلية مقارنة بللسلالة الحسلسة للتجهيزة

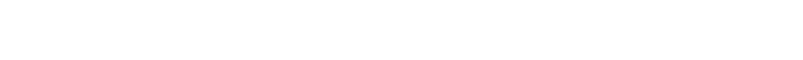
القيم الحيوي، بينما التجهيزة المعة معمليا لظٔلهرت حالة المبالة تحطل فائق.
اليسر والتي تتكون من لمباداسيهالوثرين 0\% + كللسيوم

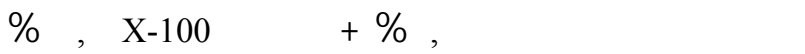
ولذك فهي تعد التجهيزة الأكثر ثباتا مقارنة مع التجهيزة الثانية (F2) التي أعطت حهم الفصل الكريمي 9. الماء العسر و ·مل في الماء اليسر وهذه التجهيزة تتكون من لمباداسيهالوثرين 0\% + كالسيوم دونيسل بذزينسالفونات

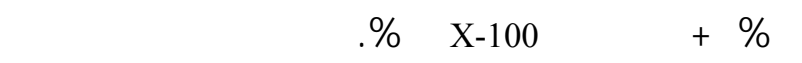

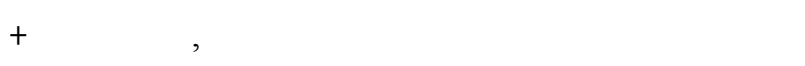

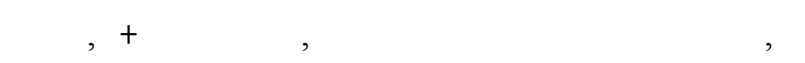
زيت في الماء اليسر.

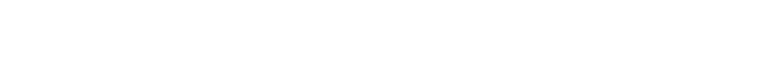

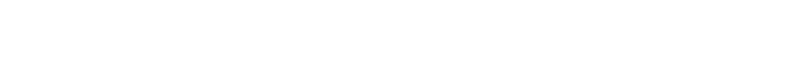

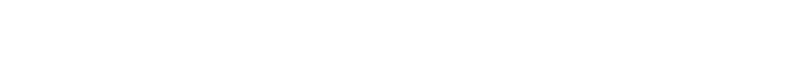

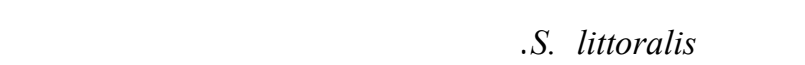
Sylgard 309

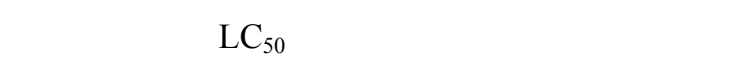

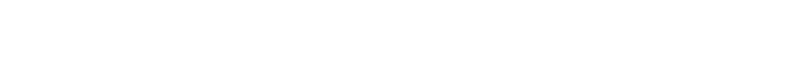
r ا, · ا جزء في المليون وبعد الضفة المنثط كانت النتيجة

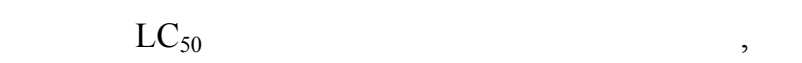
التجارية من كلوربيريفوس بمفردها وبعد اضضفة المنشط

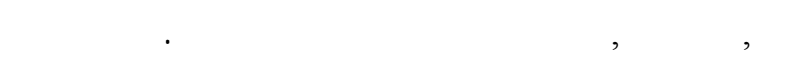

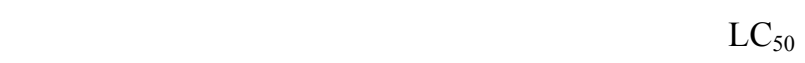
10,V .

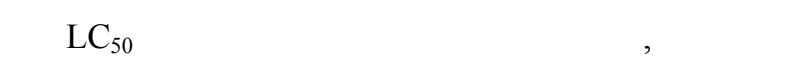

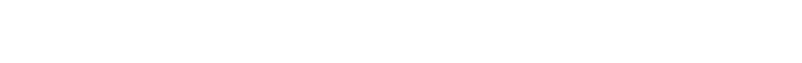

